\title{
Double Skin Façade: The State of Art on Building Energy Efficiency
}

\author{
Mostafa M. S. Ahmed, Ali K. Abel-Rahman, Ahmed Hamza H. Ali, and M. Suzuki
}

\begin{abstract}
One of the most important methods of saving energy in a building is by carefully designing its facade. A 'double skin facade' is optimally one of the best options in managing the interaction between the outdoors and the internal spaces. It also provides some architectural flexibility to the design. Double skin façade (DSF) building is one of the available energy conservation opportunities through recent intelligent buildings. The need to energy conservation and sustainable development in buildings is causing a new interest towards passive solar systems. This paper will survey the various types of double skin facades systems, exploring their features and functioning followed by a review of examples; both constructed and proposed, from different buildings. The paper will then assess and analyze recent research and examples to attempt to reach a conclusion as to whether with a double skin façade, minimizing energy consumption within building.

Finally, double skin facade (DSF) has been proven to be highly useful and significant in current building developments. The only downside of double skin facade is that it is said to be more expensive than the traditional single glass facade. However, it is widely agreed by many experts that double skin facade (DSF) is more cost-effective in the long run. This is because it is long lasting and more durable as compared to the single glass facade
\end{abstract}

Index Terms-Double skin façade, energy saving, ventilated façade.

\section{INTRODUCTION}

With the emergence of energy-consumption reduction as a major national concern, the search for better approaches and strategies in ameliorating energy efficiency of buildings is rapidly increase. Buildings construction sector are known as a major energy consumers. Their operational energy is commonly supplied in the form of electricity which is generated from fossil fuels. Overall, studies reported that buildings energy use constitutes about one third of the global final energy use [1]. This was equivalent to almost a quarter of the global $\mathrm{CO}_{2}$ emissions.

It has become necessary to take immediate action to avoid dangerous consequences for future generations. Consequently, the level of interest in Double Skin Facades (DSF) has grown rapidly due to the benefits claimed in terms of energy conservation that contributes towards sustainable development, the underlying aim of which is to meet the needs of the present without adversely affecting the ability of future

Manuscript received October 30, 2014; revised January 26, 2015. This work was supported Egyptian Ministry of Higher Education (MoHE) as well as the Egypt Japan University of Science and Technology (E-JUST).

The authors are with Egypt-Japan University of Science and Technology, Egypt (e-mail: Mostafa.ahmed@ejust.edu.eg, ali.kamel@ejust.edu.eg, ahmed.hamza@ejust.edu.eg, masaaki@chemeng.titech.ac.jp). generations to meet their own needs [2].

Double-skin façade is a multiple layer skins construction with an external skin (usually glass material), an intermediate space and an internal skin (usually glass material too) outside modern buildings [3]. The DSF concept depends on evacuating the solar radiation absorbed by the glazing envelope which enhancing ventilation within the building. As a consequence, minimizing energy consumption used for both cooling and heating [4]. However, its implementation is accompanied by significant challenges due to the complexity of the thermal and airflow phenomena involved in its behaviour as well as the adaptability of these solutions to climatic conditions of different geographical regions [5].

Therefore, this paper will review present studies about experimental and computational simulation of DSFs strategies using natural ventilation to achieve low energy consumption within buildings to draw conclusions about their implementation in naturally ventilated buildings.

\section{THEORETICAL BACKGROUND}

\section{A. Definition of Double Skin Facade System}

There are various definitions of the DSF System.

Oesterle et al. [6] gave the most comprehensive definition of DSF. For the author, a double skin façade consists of a multi layered façade envelope, which has an external and internal layer that contains a buffer space used for controlled ventilation and solar protection.

According to Ding et al. [7] "Double-skin facade is composed of an external facade, an inter-mediate space and an inner facade. The outer facade layer (glazing) provides protection against the weather and improved acoustic insulation against external noise. An adjustable sunshade device, such as blinds, is usually installed in the intermediate space to protect the internal rooms from high cooling loads caused by insulation".

Kim and Song [8], Wong [9] supported that: "Double-skin facades are multiple layer skins construction with an external skin, an intermediate space and an inner skin. The external and internal skins could be of either single glaze or double glazed glass panes of float glass or safety glass. An adjustable sun shading device is usually installed at the intermediate space for thermal controls. The double-skin constructions generally could be grouped under Box Window facade, Shaft-box facade, Corridor facade and Multi-story facade".

According to Baldinelli [10] indicated that; "Compared to a single-skin facade, a DSF consists of an external glazing offset from an internal glazing integrated into a curtain wall, often with a controllable shading system located in the cavity 
between the two glazing systems. Typically, the external glaring is a single layer of heat-strengthened safety or laminated safety glass, while the interior layer consists of single- or double pane glass with or without operable windows".

Chan et al. [11] contended that: "Double skin facade refers to a building facade covering one or several stories with multiple glazed skins. The skins can be air tight or naturally/mechanically ventilated. The outer skin is usually a hardened single glazing and can be fully glazed. Inner skin can be insulating double glazing and is not completely glazed in most applications. The width of the air cavity between the two skins can range from $200 \mathrm{~mm}$ to more than $2 \mathrm{~m}$. An air-tightened double skin facade can provide increased thermal insulation for the building so as to reduce the heat loss in winter season. On the other hand, moving cavity air inside a ventilated double skin facade can absorb heat energy from the sun-lit glazing and reduce the heat gain as well as the cooling demand of a building”.

\section{B. Concept and Functionality of the Double Skin Façade}

The concept of DSF was introduced in early 1900s, but little progress was made until the 1990s [12]. The history of DSF is not particularly established and knowledge on the physical processes involved is still lacking. Although its use is more popular in places with more stringent building energy performance regulations, most countries do not have any standard guidelines on how to design and assess the performance of DSF, which can be a barrier for its implementation [13].

A DSF consists of a normal façade, an air cavity and an additional external skin usually made of glass. It is a common practice to implement a shading system within the cavity between the two layers of the façade. According to Gracia $e t$ al. [14] the main factors that encourage air movement in buildings with DSF are the movement of the surrounding wind and the pressure difference due to the thermal buoyancy that occurs in the cavity. The phenomenon of thermal chimney within the DSF occurs due to the density difference between the warmer air inside the cavity and the cooler air outside. The air inside the cavity is warmed up by the solar radiation and exhausted to outside from the top of the cavity. In naturally ventilated building, fresh air is often drawn from windows on the opposite side of the DSF, which passes through the occupant space before being extracted into the cavity of the DSF [15].

\section{Classification of Double Skin Facades}

There are different ways to classify Double Skin Facade systems. The systems can be categorized by the type of construction, the origin, destination and type of the air flow in the cavity, etc.

The Environmental Engineering firm of Battle McCarthy in Great Britain created a categorization of five primary types (plus sub-classifications) based on commonalities of façade configuration and the manner of operation. These are [16]:

1) Category A: Sealed Inner Skin: subdivided into mechanically ventilated cavity with controlled flue intake versus a ventilated and serviced thermal flue.

2) Category B: Openable Inner and Outer Skins: subdivided into single story cavity height versus full building cavity height.

3) Category C: Open-able Inner Skin with mechanically ventilated cavity with controlled flue intake

4) Category D: Sealed Cavity either zoned floor by floor or with a full height cavity.

5) Category E: Acoustic Barrier with either a massive exterior envelope or a lightweight exterior envelope.

The study by Lou et al. [17] introduces three design strategies for DSFs including continuous, box and corridor DSFs as shown in Fig. 1. On the other hand, a similar study by Heusler and Compagno [18] categorizes the DSFs into three types of window, story and multiple stories' as represented in Fig. 2.

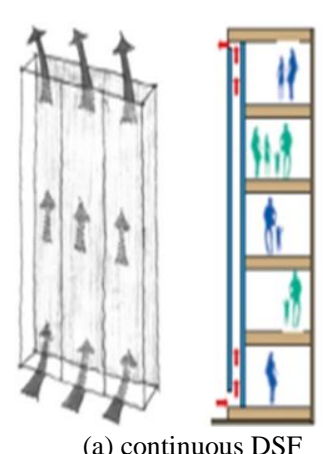

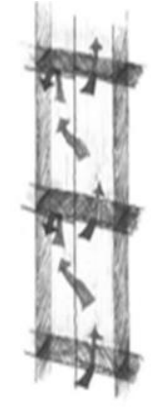

(b) box DSF

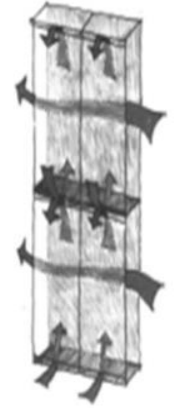

(c) corridor DSF

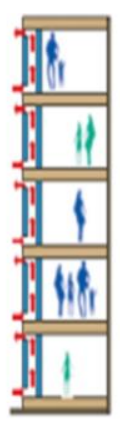

Fig. 1. Main design strategies of DSFs [19].

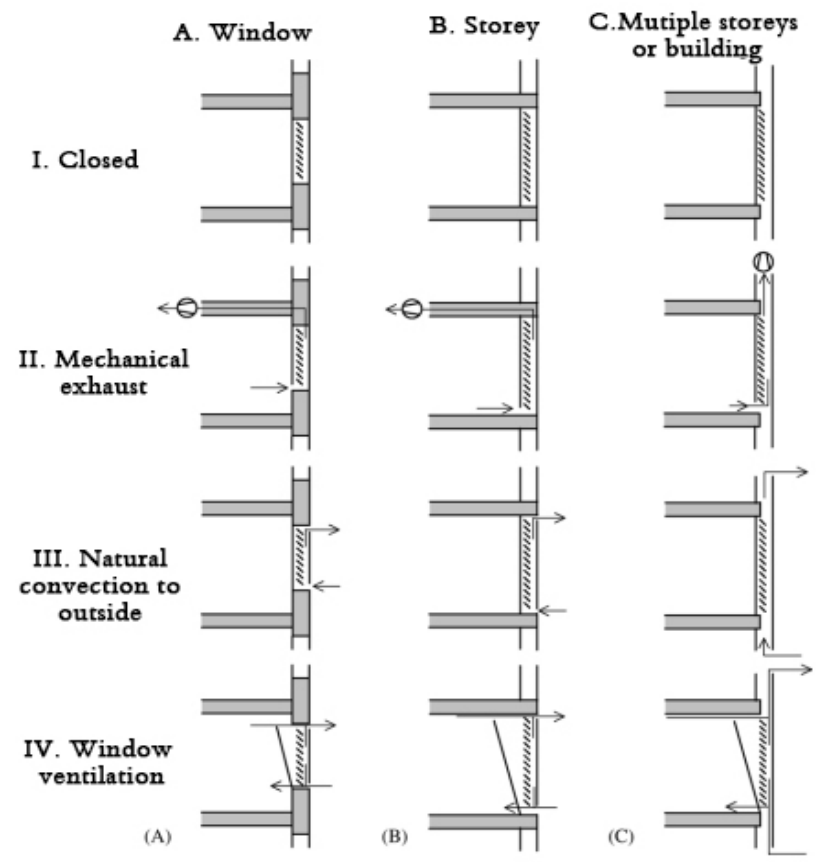

Fig. 2. Categorization of DSFs [20].

\section{Advantages and Disadvantage of the Double Skin Façade Concept}

\section{1) Advantage of the double skin façade concept}

The primary benefits attributed to DSF are their ability to save energy and permit day lighting of the internal spaces of the building. In regard to the reduction in energy use, DSF are credited with the ability to mitigate the impact of the prevailing climatic and environmental conditions on the interior of a building, allowing a reduction in the size, extent 
and operation of a building's Heating, Ventilation and Air Conditioning (HVAC) systems. In some cases DSF have been credited with eliminating the need for air conditioning altogether. Battle McCarthy, a United Kingdom based engineering and landscape architectural practice, state on their website that ".... double skin buildings are able to reduce energy consumption by $65 \%$, running costs by $65 \%$ and cut $\mathrm{CO}_{2}$ emissions by $50 \%$, in the cold temperate climatic prevalent in the United Kingdom when compared to advanced single skin building." [21].

Reducing heating demand. DSF achieve this in a number of ways. Firstly, the cavity between the inner and outer skin forms an additional layer of insulation to the building, preventing heat loss. Secondly, warm air in the cavity can be used to preheat fresh air being introduced into the building for ventilation. Thirdly, extensive glazing allows sunlight to be used for passive heating of the interior of the building [21].

Controlling solar gain. In warmer months and climates, the cooling demand can be very high due to solar gain through windows and the fabric of buildings. DSF can reduce the impact of this solar gain by allowing shading devices to be installed in the cavity between the two skins, preventing sunlight from reaching the inner skin. The shading devices are normally adjustable to ensure that views through the highly glazed façade are retained as much as possible. Warm air trapped within the cavity can be expelled by natural and/or mechanical ventilation to prevent it from heating up the interior of the building. The cavity protects the shading devices from rain and wind, especially on tall buildings, as well as providing access for maintenance of these devices [21].

Energy savings and reduced environmental impacts: In principle, Double Skin Façade can save energy when properly designed. Often, when the conventional insulation of the exterior wall is poor, the savings that can be obtained with the additional skin may seem impressive. According to Arons and Glicksman [22], energy savings attributed to double skin façades are achieved by minimizing solar loading at the perimeter of buildings. Providing low solar factor and low $\mathrm{U}$ Value minimizing cooling load of adjacent spaces.

\section{2) Disadvantages of the double skin façade concept}

The disadvantages mentioned in literature concerning the Double Skin Façade concept are described below:

Higher construction costs compared to a conventional façade. As Oesterle et al. [6], describe, "no one would dispute that double skin facades are more expensive than single skin forms: the construction of the outer layer and the space between the two skins makes the former type more elaborate".

Additional maintenance and operational costs: Comparing the Double Skin and the Single Skin type of façade, one can easily see that the Double Skin type has higher cost regarding construction, cleaning, operating, inspection, servicing, and maintenance [16]. Oesterle et al. [6], give an extensive description of the method to estimate the costs. As he claims, still there is not a very efficient way to estimate the costs.

\section{Passive Ventilation AND Double-Skin FAÇADE}

The need to energy conservation and sustainable development in buildings is causing a new interest towards passive systems. Among them, double-skin facade (DSF) proves to be passive ventilated façade.

Many of interesting investigations and findings are reported in the literature relating to passive ventilation in buildings and the thermal performance of double-skin facades. Although most of the researches are done mainly in moderate countries conditions but they have revealed close link between natural ventilation design and the function of double-skin facade.

According to Oesterle et al. [6], significant energy savings can be achieved only where Double Skin Facades make window ventilation possible or where they considerably extend the period in which the natural ventilation can exploited.

Reduction of the wind pressure effect: the double skin façades around high rise buildings can serve to reduce the effect of wind pressure.

Allowing natural ventilation in DSF by operable windows in the inner skin is believed to significantly reduce the load on the HVAC system by providing fresh air and cooling comfort for the occupants of a building. DSF can allow for natural ventilation even in high rise buildings by providing protection for windows in the inner skin from wind and weather. DSFs can also be used for passive night time cooling of a building's structure, and a stack effect can be created within the cavity to improve cross ventilation and purge hot air from the building [21].

Gratia and Herde [23] attempted to look at the impact of double-skin facade facing southern direction in a temperate climatic condition. Thermal analysis using simulation software of different seasons of a year was done for a low-rise office building with and without double-skin façade. It was found that significant energy saving is possible if natural ventilation could be exploited through the use of double-skin façade.

\section{The RELATIONSHIP BETWEEN DOUbLE SKIN FAÇADE AND SAVING ENERGY IN BUILDING}

Many studies recommend the application of double-skin facades for reducing the heat gains as an energy efficient feature for development of low energy buildings [24], [25]. Shameri et al. [5] explicitly introduces the adoption of double-skin facades as an effective solution for the goal of energy saving in buildings. In principal, the combination of two façade layers with an empty space inside (air gap - cavity) develops the idea of DSFs [26]. Gratia [27] explains that double-skin facades are derived progressively from the concept of a façade deigned entirely by glass. On the other hand, referring to the study by Mingotti et al. [28], the external and internal layers of DSFs must have versatile openings in order to ensure air ventilation within the cavity as well as the interior atmosphere of the adjacent interior spaces. In view of that, it is reflected that the temperature and air ventilation are inherently related to the size of cavity, hence, the studies by Balocco and Colombari [29], Balocco [30] confirm that once the widths of cavity gets decreased, there is a high risk of being confronted with an overheating façade 
layer particularly, in summer. Nonetheless, in general, in double-skin facades, there is an opportunity of adding an extra glaze skin to the building which could provide enhanced visual comfort, improved daylighting and progressive energy performance. The incorporation of the external and internal façade layers in DSFs also has impact on greenhouse effect as visualized by Gratia and Herde [27] in Fig. 3.

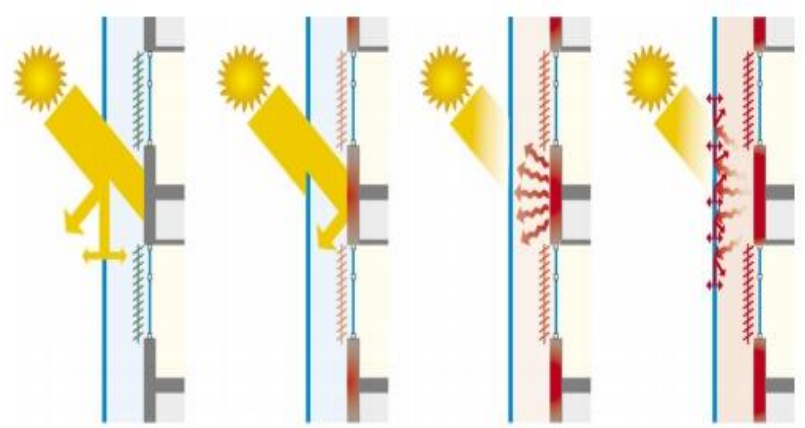

Fig. 3. The incorporation of the external and internal façade layers [27]

Meanwhile, with view to the sustainable energy performance of DSFs, according to the study by Chan et al. [11], the heat transfer and air movement within a section of DSF is represented (see Fig. 4).

It is important to consider that the air movement in DSFs varies to suite the environmental requirements; hence, Haase et al. [31] identifies five types of air movement for application in DSFs which are visually represented in Fig. 5.

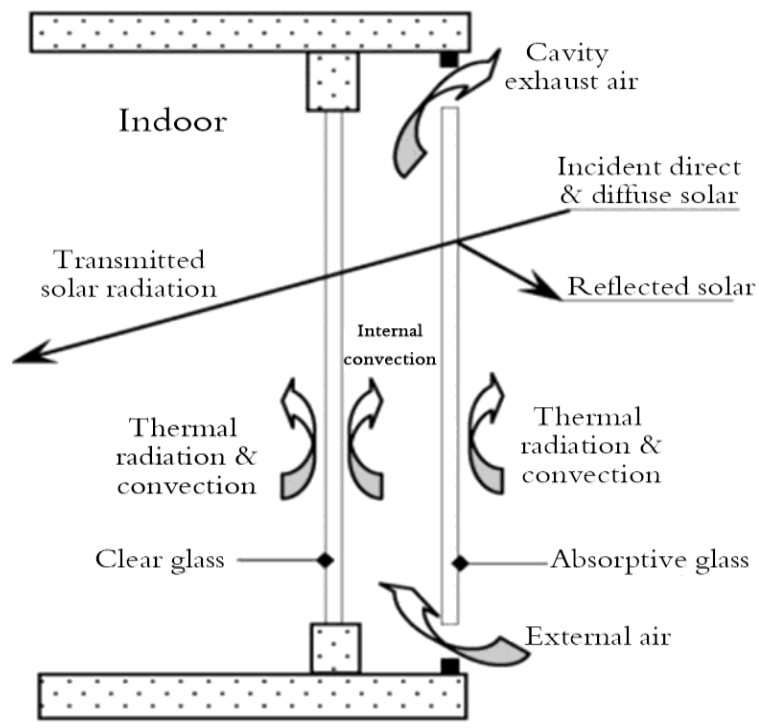

Fig. 4. The heart transfer and air movement in DSFs [11].

Adding to the strengths of double-skin facades, Yilmaz and Cetintas [4] highlights other positive effects including the sound insulation and enhanced aesthetic features besides sustainable energy performances. Similarly, Byrd and Leardini [32] draws attention to the role of DSFs as the preventing system for decreasing the noises while arguing that despite the repeatedly discussed benefits of DSFs as energy efficient systems, it is difficult to measure this effectiveness based on the statement by Lawrence Berkeley National Laboratories [33].

On the contrary, other studies have explicitly ascertained the effective result of DSFs for reducing the energy consumptions, particularly with respect to the cooling demands.

Thereby, it is inferred that there is still a need for future research towards the further analysis, verification and potential reinforcement of these facades to ensure enhanced building energy performances.

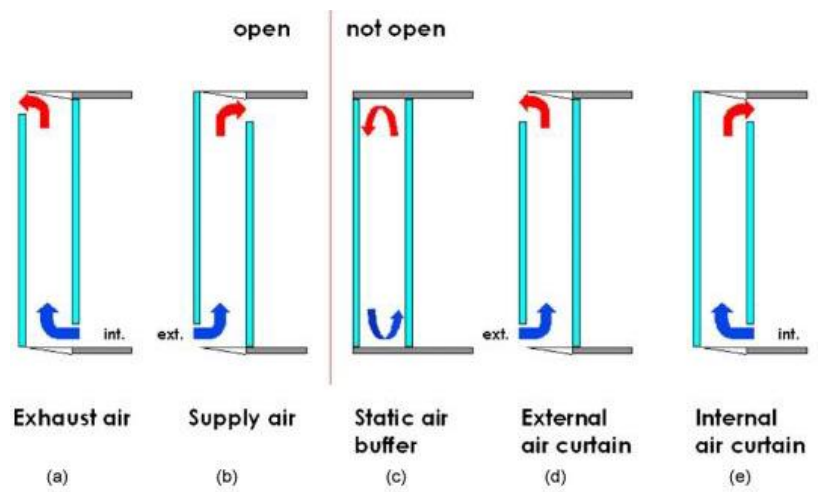

Fig. 5. Main types of air movement in DSFs [31].

Looking retrospectively, these facades could also be classified based on their construction types and the circumstances of ventilations. Thereby, in view of the construction types, there are continuous and interrupted double-skin facades while with regards to the ventilation, facades are divided into natural ventilated, mechanical ventilated as well as natural and mechanical ventilated [4]. According to the studies by Yilmaz and Cetintas [4] and Chou et al. [24], it is inferred that in summer, the reduction of solar heat gain is the main effect of double-skin facades while in winter; double-skin facades help to minimize the heat loss and improve the u-values. According to the study by Høseggen et al. [34], comparing the single and double-skin facades, the simulations confirm that the application DSFs reduces the heating energy demand in buildings.

To improve the effectiveness of DSFs, unlike the conventional DSFs, Ding et al. [7] proposes to add a thermal storage as solar chimney above the double-skin layers in order to improve the ventilations (Fig. 6). The analysis confirms the effectiveness of the proposed concept in order to be utilized for intelligent façade design developments.

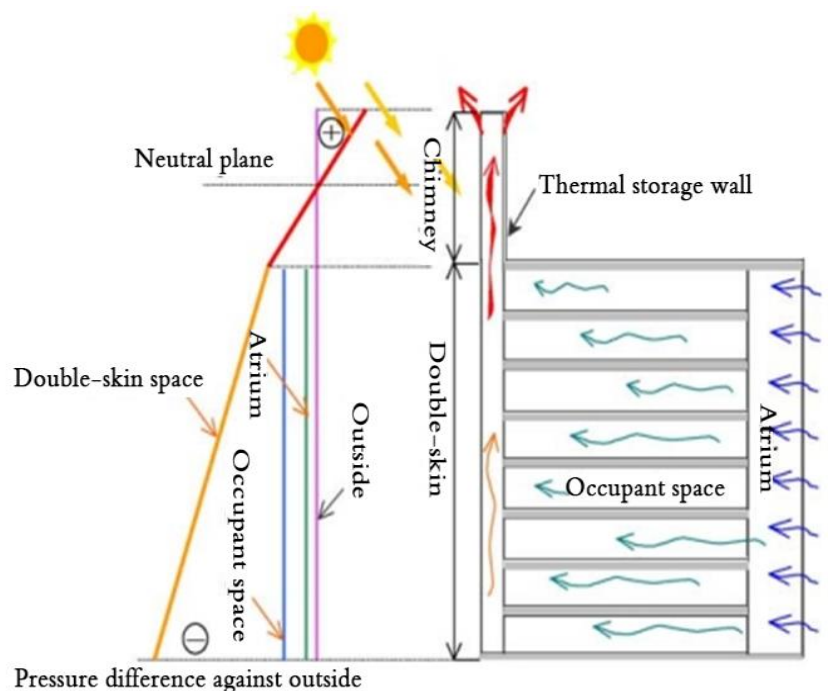

(+: Positive to outside: -: Negative to ouside)

Fig. 6. Application of solar chimney as the thermal storage in DSFs [7]. 
Analyzing the essence of double-skin facades, Shameri et al. [5] concludes that DSFs are essentially influential for enhancement of building energy performance. One of the few challenges for the application of DSFs is their cost compared to the conventional facades. Andresen [35] also highlights the required cost for development of DSFs is approximately $60-80 \%$ more than the conventional types. Nevertheless, it is also elaborated that DSFs embody the concept of cost efficiency in long-time duration. Meanwhile, Shameri et al. [5] expresses the 'fire hazard risks' as another challenge of DSF application which requires further research and investigation.

\section{Simulation, MODELING AND EXPERIMENTS OF DSF}

One of the most emerging techniques available to engineers and designers are computer modelling and simulation [36]. Experimental and numerical models were used for studying the DSF. Models that were used for predicting and analyzing DSF include analytical and lumped models, dimensional analysis, network models, control-volume models and Computational Fluid Dynamics (CFD). Lumped model was used for naturally ventilated DSF.

Dimensional analysis was used to describe the energy performance of different DSF designs. Balco [37] proposed a non-dimensional analysis involving energy and thermal properties for a natural ventilated double facade. The non-dimensional analysis results were validated with experimental and CFD simulation results. The method can be applied to all natural ventilated facade typology.

Furthermore, Stec and Paassen 2005 [38] compared the performance of nine different facade systems for Dutch climate and concluded that the double skin systems were competitive in energy performance. They also stressed on the importance of treating the double-skin as an integrated part of the HVAC system. Moreover, they emphasised on evaluating the energy performance of office buildings with DSF.

\section{CONCLUSION}

In conclusion, double skin facade (DSF) has been proven to be highly useful and significant in current building developments. The only downside of double skin facade is that it is said to be more expensive than the traditional single glass facade. However, it is widely agreed by many experts that double skin facade (DSF) is more cost-effective in the long run. This is because it is long lasting and more durable as compared to the single glass facade. In addition, it provides other benefits that cannot be found in single glass facade. One of it is that double skin facade helps create a more comfortable and eco-friendly office environment which in turn, further reduces maintenance costs as it saves the building's energy resources.

Finally, DSF systems have great potential for decrease energy consumption in wide ranges of research areas. The systems based on the ideal can find significant opportunities to be used in some innovative and prospective studies with multidisciplinary research.

Thus, the researchers of this study propose future works and more studies to be done on DSF designs, on the problems in DSF designs and its impact on the environment, building ergonomics and human psychology, and comfort. Innovations in DSF designs should be further pursued and DSF applications in buildings should seriously be considered as an element in addressing climatic changes and environmental hazards as it is cost and energy efficient.

\section{ACKNOWLEDGMENT}

The first author would like to thank Egyptian Ministry of Higher Education (MoHE) for providing him the financial support (PhD scholarship) for this research as well as the Egypt Japan University of Science and Technology (E-JUST) for offering the facility and tools needed to conduct this work.

\section{REFERENCES}

[1] G. B. Hanna, "Green energy and green buildings in Egypt," Int. J. Eng. Res. Appl., vol. 3, no. 4, pp. 466-470, 2013.

[2] N. Safer, M. Woloszyn, J. J. Roux, and F. Kuznik, "Modeling of the double-skin facades for building energy simulations: Radiative and convective heat transfer," Building Simul., pp. 1067-1074, 2005.

[3] J. Zhou and Y. Chen, "A review on applying ventilated double-skin facade to buildings in hot-summer and cold-winter zone in China," Renew. Sustain. Energy Rev., vol. 14, no. 4, pp. 1321-1328, May 2010.

[4] Z. Yılmaz and F. Çetintaş, "Double skin façade's effects on heat losses of office buildings in Istanbul," Energy Build., vol. 37, no. 7, pp. 691-697, Jul. 2005.

[5] M. A. Shameri, M. A. Alghoul, K. Sopian, M. F. M. Zain, and O. Elayeb, "Perspectives of double skin façade systems in buildings and energy saving," Renew. Sustain. Energy Rev., vol. 15, no. 3, pp. 1468-1475, Apr. 2011.

[6] W. Oesterle, E. Lieb, R-D. Lutz, and M. Heusler, "Double skin facades - Integrated planning," Prestel Verlag Munich, Ger., 2001.

[7] W. Ding, Y. Hasemi, and T. Yamada, "Natural ventilation performance of a double-skin façade with a solar chimney," Energy Build., vol. 37, no. 4, pp. 411-418, Apr. 2005.

[8] S. Y. Kim and K. D. Song, "Determining photosensor conditions of a daylight dimming control system using different double-skin envelope configurations," Indoor Built Environ., vol. 16, no. 5, pp. 411-425, Oct. 2007.

[9] P. Wong, "Natural ventilation in double-skin façade design for office buildings in hot and humid climate," University of New South Wales, Australia, 2008.

[10] G. Baldinelli, "Double skin façades for warm climate regions: Analysis of a solution with an integrated movable shading system," Build. Environ., vol. 44, no. 6, pp. 1107-1118, Jun. 2009.

[11] A. L. S. Chan, T. T. Chow, K. F. Fong, and Z. Lin, "Investigation on energy performance of double skin façade in Hong Kong," Energy Build., vol. 41, no. 11, pp. 1135-1142, Nov. 2009.

[12] P. D. Pomponi et al., "Assessment of double skin façade technologies for office refurbishments in the United Kingdom," Sustain. Build. Constr. Prod. Technol. Graz, 2013.

[13] J. H. W. Choi, J. Joe, and Y. Kwak, "Operation and control strategies for multi-storey double skin facades during the heating season," Energy Build., vol. 49, pp. 454-465, 2012.

[14] A. De Gracia, A. Castell, L. Navarro, E. Oró, and L. F. Cabeza, "Numerical modelling of ventilated facades: A review," Renew. Sustain. Energy Rev., vol. 22, pp. 539-549, Jun. 2013.

[15] H. Radhi, S. Sharples, and F. Fikiry, "Will multi-facade systems reduce cooling energy in fully glazed buildings? A scoping study of UAE buildings," Energy Build., vol. 56, pp. 179-188, Jan. 2013.

[16] H. Poirazis, "Double skin facades- A literature review," A Rep. IEA SHC Task 34 ECBCS Annex 43, 2006.

[17] W. Lou, M. Huang, M. Zhang, and N. Lin, "Experimental and zonal modeling for wind pressures on double-skin facades of a tall building," Energy Build., vol. 54, pp. 179-191, Nov. 2012.

[18] C. A. Heusler, "Multiple-skin facades," Fassade Façade, vol. 1, pp. 15-21, 1998.

[19] W. Lou, M. Huang, M. Zhang, and N. Lin, "Experimental and zonal modeling for wind pressures on double-skin facades of a tall building," Energy Build., vol. 54, pp. 179-191, Nov. 2012. 
[20] H. Manz and T. Frank, "Thermal simulation of buildings with double-skin façades," Energy Build., vol. 37, no. 11, pp. 1114-1121, Nov. 2005.

[21] L. Author and B. Pollard, "Double skin façades more is less ?," in Proc. Int. Sol. Energy Soc. Conf., 2000, vol. 21, pp. 1-25.

[22] L. R. Arons and D. M. M. Glicksman, "Double skin, airflow facades: Will the popular european model work in the USA?" in Proc. ICBEST 2001, Int. Conf. Build. Envel. Syst. Technol. Ottawa, Canada, 2001, vol. 1, pp. 203-207.

[23] E. Gratia and A. De Herde, "Optimal operation of a south double-skin facade," Energy Build., vol. 36, no. 1, pp. 41-60, Jan. 2004.

[24] S. K. Chou, K. J. Chua, and J. C. Ho, "A study on the effects of double skin façades on the energy management in buildings," Energy Convers. Manag., vol. 50, no. 9, pp. 2275-2281, Sep. 2009.

[25] M. T. Weir, "Energy and environmental impact analysis of double-glazed windowsconvers," Energy Convers Manag., vol. 39, no. 3, pp. 243-256, 1998.

[26] N. Hamza, "Double versus single skin facades in hot arid areas," Energy Build., vol. 40, no. 3, pp. 240-248, Jan. 2008.

[27] E. Gratia and A. De Herde, "Greenhouse effect in double-skin facade," Energy Build., vol. 39, no. 2, pp. 199-211, Feb. 2007.

[28] N. Mingotti, T. Chenvidyakarn, and A. W. Woods, "The fluid mechanics of the natural ventilation of a narrow-cavity double-skin facade," Build. Environ., vol. 46, no. 4, pp. 807-823, Apr. 2011.

[29] C. Balocco and M. Colombari, "Thermal behaviour of interactive mechanically ventilated double glazed façade: Non-dimensional analysis," Energy Build., vol. 38, no. 1, pp. 1-7, Jan. 2006.

[30] C. Balocco, "A simple model to study ventilated facades energy performance," Energy Build., vol. 34, no. 5, pp. 469-475, Jun. 2002.

[31] M. Haase, F. Marques da Silva, and A. Amato, "Simulation of ventilated facades in hot and humid climates," Energy Build., vol. 41, no. 4, pp. 361-373, Apr. 2009.

[32] H. Byrd and P. Leardini, "Green buildings: Issues for New Zealand," Procedia Eng., vol. 21, pp. 481-488, Jan. 2011.

[33] Lawrence Berkeley National Laboratories, "High Performance Commercial Building facades."

[34] R. Høseggen, B. J. Wachenfeldt, and S. O. Hanssen, "Building simulation as an assisting tool in decision making," Energy Build., vol. 40, no. 5, pp. 821-827, Jan. 2008.

[35] I. Andresen, "Dobbeltfasader (double-skin facades)," SINTEF Technol. Soc. Rep. no. STF22 A01016, Trondheim, Norw., 2002.

[36] M. Bartak, F. Drkal, J. Hensen, and M. Lain, "ESP-r: Integrated simulation tool for design example 1: A modern office building in Prague," in Proc. Int. Workshop of Integrated Build. Simulation, pp. 108-116, 2003.

[37] C. Balocco, "A non-dimensional analysis of a ventilated double façade energy performance,” Energy Build., vol. 36, no. 1, pp. 35-40, Jan. 2004.

[38] W. J. Stec and A. H. C. Van Paassen, "Symbiosis of the double skin façade with the HVAC system," Energy Build., vol. 37, no. 5, pp. 461-469, May 2005.

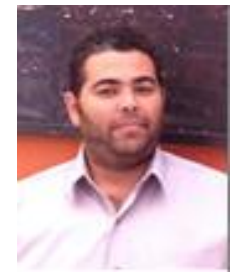

Mostafa M. S. Ahmed was born in Assuit, Egypt, on June 15, 1981. Mostafa got the degree of master of science in architecture engineering from Assiut University in September 2012. He was awarded full scholarship to the Egypt-Japan University of Science and Technology (E-JUST), Alexandria, Egypt for Ph.D. Program on September 2013. Currently, Ahmed is a Ph.D. student in Energy Resources Engineering Department at E-JUST. His research interests are double skin facades, dynamic facades, and energy efficiency within intelligent buildings.

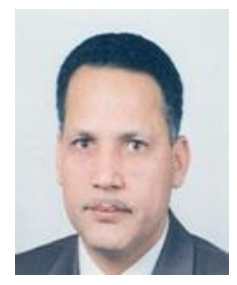

Ali K. Abdel Rahman was born in Sohag, Egypt, on October 2, 1954. He received the Ph.D. degree in mechanical engineering from Kyoto University, Japan, in 1992. Currently, he is the chairperson of Department of Energy Recourses Engineering at Egypt-Japan University of Science and Technology (E-JUST). His research interests are heat transfer, fluid mechanics, thermodynamics, solar energy, and renewable energy.

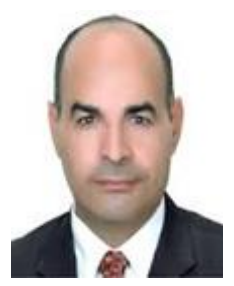

Ahmed Hamza H. Ali was born in Elsharkia, Egypt, on December 16, 1963. He obtained the doctora degree in engineering from Muroran Institute of Technology, Hokkaido, Japan, in April 1999. Currently, he is the director of Research Excellence Center for Energy Resources and Management EJUST at Egypt-Japan University of Science and Technology (E-JUST). His principal areas of research and expertise: currently leading activities in the basic and applied research in renewable energy systems including solar energy cooling and heating systems, nocturnal radiation cooling systems, solar power generation, thermal energy storage systems, thermal analysis for cooling and heating of buildings including industrial energy audit and energy efficiency.

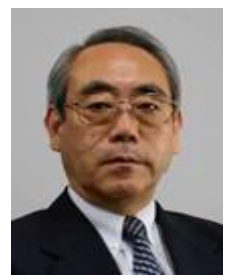

Masaaki Suzuki was born in January 12th, 1949 in Japan. He graduated from Tokyo Institute of Technology in 1972, and after that, he received master degree in 1975 and doctoral degree in 1978 from Tokyo Institute of Technology. He has worked in Tokyo Institute of Technology throughout until retirement, from 1978 as a research associate, from 1990 as an associate professor, from 1999 as a professor. In this career, he worked as an exchange researcher in University of Minnesota, U.S.A. from 1979 to 1981. In March 2014, he retired and was decorated with the title of Professor Emeritus, Tokyo Institute of Technology.

Prof. Masaaki Suzuki was nominated as First Japanese Vice president of E-JUST, and approved by the Board. He had been engaged in E-JUST establishment project from its beginning in 2009 as representative of Tokyo Institute of Technology under the Technical Cooperation of Japan International Cooperation Agency (JICA), and has been worked as an academic advisor from last March 2014 in E-JUST. 